УДК 1(09)

DOI: $10.18384 / 2310-7227-2017-3-81-87$

\title{
ИДЕЯ ПАТРИОТИЧЕСКОЙ ОСНОВЫ ЛИЧНОСТИ В ФИЛОСОФИИ И.А. ИЛЬИНА
}

\section{Потапенко Т.В.}

Московский государственный областной университет

105005, г. Москва, ул. Радио, д. 10А, Российская Федерация

\begin{abstract}
Аннотация. Признаком транзитивности, неустойчивости современного общества является утрата им базовых моральных ориентиров. В непростых условиях, когда новые моральные принципы только находятся в стадии формирования, молодому поколению предстоит сделать нравственный выбор. Этот выбор должен базироваться на высоком уровне духовного развития личности. В данном случае патриотизм выступает в качестве фундаментальной основы личности, о чём говорил русский философ первой половины $\mathrm{XX}$ в. И.А. Ильин, разрабатывая универсальную методику патриотического воспитания личности. Вне социальной среды личность десрормируется, теряя гармонию и целостность. В статье сделаны выводы о приоритетности духовного начала в фрормировании патриотизма у личности, что в конечном счёте является основой гуманного общества. Автором статьи использованы методы историко-фрилософского анализа: сравнительного философрского анализа, историко-философской реконструкции, интерпретации.
\end{abstract}

Ключевые слова: патриотизм, духовность, личность, нравственность, целостность.

\section{THE IDEA OF PATRIOTIC FOUNDATIONS OF PERSONALITY IN I.A. ILYIN'S PHILOSOPHY}

\section{T. Potapenko}

Moscow Region State University

10A, Radio st., Moscow, 105005, Russian Federation

\begin{abstract}
The sign of transitivity, instability of the modern society is the loss of its basic moral guidelines. In difficult conditions, when new moral principles are only in the process of formation, the young generation will have to make a moral choice. This choice should be based on a high level of spiritual development of the individual. In this case, according to the Russian philosopher of the first half of the twentieth century, I.A. Ilyin, patriotism acts as the fundamental basis of the individual. I.A. Ilyin developed a universal method of patriotic education. Outside social environment, the personality gets deformed losing its harmony and integrity. By using the methods of a comparative philosophical analysis, historical-philosophical reconstruction, and the method of interpretation the author of the article argues the priority of the spiritual principle in inspiring patriotism in the personality, which ultimately forms the basis of the humane society.
\end{abstract}

Key words: patriotism, spirituality, identity, morality, integrity.

(с) Потапенко Т.В., 2017. 
В современном мире на переломных этапах развития общества, когда оно теряет моральные принципы и нормы, существовавшие до этого времени, а новые туманны и находятся в стадии формирования, очень важным и актуальным становится формирование у подрастающего поколения способности делать морально-нравственный и духовный выбор, в основе которого будет лежать высокодуховное личностное развитие. В этом случае патриотизм выступает фундаментальной основой становления личности [9].

Универсальным методом патриотического воспитания личности является приобщение её к традициям и культурному достоянию своего народа, отечества, той социальной среды, из которой она происходит. Отказ от духовности в системе патриотического воспитания ведёт к деформации самой личности и утрате ею гармоничности и целостности.

Любой человек - это в первую очередь личность, имеющая свои собственные идеалы, этические и моральные нормы, ценностные ориентиры, неповторимый внутренний мир. Нравственное воспитание личности, её духовный потенциал дают возможность построить гуманное общество, которое является одной из главных основ современного мира. «Духовный, т. е. ценностный кризис тем отличается от всех других кризисов, что здесь человек как бы потерял самого себя, то, с чем он себя идентифицировал, веровал...» [1, с. 143]. Именно поэтому на сегодняшний день наиглавнейшей задачей современного общества становится возрождение духовности и нравственности при формировании тичности у растущего поколения.
Этими вопросами неоднократно задавался и русский философ и публицист Иван Александрович Ильин (09.04.1883-21.12.1954). Отличительной чертой его философии являются широта охватываемых им тем, углублённость в них с точки зрения православно-религиозного мировоззрения, патриотичность, духовность его учений [4].

Иван Александрович уделял огромное внимание в своём творчестве развитию морально-нравственных, духовных и патриотических качеств личности. Личность им рассматривалась с точки зрения духовности, которая включает в себя опыт нравственности и религиозности [3].

Главными аспектами духовности в формировании личности философ считает формирование в ней таких духовных качеств, как патриотические, религиозные, нравственные и эстетические [10].

Ильин в своих трудах всё время затрагивает тему воспитания и формирования личности, её духовности и морального здоровья. Личность, обладающая такими качествами, сможет сделать верный выбор, столкнувшись с социальным и духовно-нравственным злом. Однако в этом понимании следует учитывать и то, как воспринимаются смысл человеческой жизни, её сущность и бытие. И здесь отправную точку Ильин видит в духовно-нравственном творчестве русских философов и писателей: В.С. Соловьёва, Н.В. Гоголя, Ф.М. Достоевского и многих других. Их объединяло неприятие того назначения человека и смысла его жизни, который можно назвать «философией жизни», в основе которой представление о жизни как о наи- 
высшей ценности. Философ, наоборот, говорил о несостоятельности видения смысла жизни в самой человеческой жизни. Есть иные ценности, которые находятся выше этой самой жизни, и существует «некий особый надбиологический и надсоциальный её смысл». Эти выводы можно сделать, исходя из того, что человек в первую очередь духовное существо. И из этого следует, что наивысшие ценности - религиозные, духовные и патриотические [2].

Он считал, что патриотическое воспитание - это приобщение человека как индивида к совершенному и родовому. Два разных аспекта патриотического воспитания определяют становление целостного человека. Уровень качества сопоставления моральных и духовно-нравственных критериев, с которыми личность себя идентифицирует и к которым стремится, определяет уровень её внутренней целостности, душевного и морального здоровья.

Непосредственной отправной точкой в воспитании и формировании личности является своё, родовое, кровное, национальное, родное. Отчизна, историческая память, родная культура, национальные традиции и символы - всё это в процессе патриотического воспитания осваивается и усваивается в качестве важнейшей основы самоопределения, самоидентификации личности человека и её самореализации. Формирование стремления к лучшему связано с воспитанием чувства принадлежности к национальному, родному; это даёт возможность глубже понять и принять духовное становление личности, которое и является процессом воспитания, передаваемого последующему поколению с целью развития и формирования у него способностей к нравственному выбору.

Духовная основа содержания и структуры становления личности определяет процесс патриотического воспитания в качестве коммуникационной и социокультурной связующей. Этот процесс базируется на объединении, а не разъединении его участников. Главный смысл воспитания состоит не в простой адаптации его подопечныхвоспитанников, в элементарном приспособлении к изменяющимся условиям внешней среды, а в социализации подрастающего поколения как объекта и субъекта духовно-патриотического воспитания, его эффективной адаптации, идентификации и самореализации.

Такое воспитание напрямую связано со специфическими и универсальными характеристиками его организации, предполагающей поиск оптимальных моделей и технологий патриотизации. Различные типы патриотического воспитания подразумевают дифференцированный подход при применении его конкретного типа и технологий, которые, в свою очередь, должны учитывать условия, сложившиеся на данный момент времени.

Процесс патриотического воспитания, нацеленный на своё, родное и лучшее, должен способствовать воспроизводству духовности человека, его стремлению к морально-нравственному развитию, определяющему объективно лучшую, исторически правильную и подлинно верную логику его мыслей и поступков. С этой точки зрения патриотическое воспитание является истинным развитием личности, наполнением её доблестью, верностью, героизмом, идеалами слу- 
жения отечеству, добру, совестливости и чести. Это воспитание превращает человека не просто в нравственноэтическое существо, чему, скажем, могут служить и некоторые другие виды воспитания, но и в личность духовнополноценную, социально-ответственную и действительно культурную и патриотическую [8].

И.А. Ильин считал религиозность и патриотизм живым и искренним стремлением к идеалу, который должен захватить все уголки человеческой души и привести их в движение, затрагивая все сферы его жизнедеятельности.

В своих трудах философ много раз обращался к этическим и нравственным вопросам. Ему были не безразличны проблемы справедливости, добра и зла.

Духовная основа, как и патриотизм, зарождается и становится именно в семье. Основа такого преобладания любовь родителей к собственному ребенку, любовь к ближним. Как известно, для возникновения патриотизма только одной родительской любви не хватает, а иногда она провоцирует развитие эгоизма и равнодушия в ребёнке. Важной составляющей духовной основы патриотизма является именно сама духовность, любовь к предельному, совершенному, абсолютному. Благодаря развитию именно такой любви ребёнок начинает самовоспитываться, стремясь найти именно тот глубокий смысл бъьтия, и устремляется к объективно лучшему, объективно прекрасному. Просветлённость духовнонравственного воспитания основывается на духовной любви, а патриотизм представляется через совокупность духовной и родительской любви как их общее детище. Когда такой совокупности нет, что бывает в духовно «мёртвой» семье или в отсутствии родительской любви, то ребенок становится постепенно «частным» лицом и в то же время отчужденным, а не слитым со своей семьей. А это означает, что он не патриот. Семья, таким образом, выступает не просто как социальный институт, первоначальная ячейка общества, подразделение, но как вместилище духовного очага и основа его возникновения.

Не зря Иван Александрович писал по этому поводу: «Воспитать ребёнка значит заложить в нём основы духовного характера и довести его до способности самовоспитания» [7, с. 191]. Философ считает, что семья - это «духовный очаг» патриотизма, его источник, благодаря которому человеку даётся возможность «самому войти в ту Родину, которой стоит жить и гордиться, за которую стоит бороться и умереть». Помимо воспитания в любви Ильин акцентирует внимание на таких жизненно важных функциях, возложенных на семью, как: «...поддержание из поколения в поколение отечественной традиции»; «Семья есть для ребёнка первое родное место на земле; сначала место-жилище, источник тепла и питания, потом место осознанной любви и духовного понимания»; «Семья есть для ребенка первое «мы», возникшее из любви и добровольного служения, где один стоит за всех и все за одного. Она есть для него лоно естественной солидарности, где взаимная любовь превращает долг в радость и держит всегда открытыми священные врата совести. Она есть для него школа взаимного и совместного, организованного действия. Не ясно ли, что ис- 
тинный гражданин и сын своей родины воспитывается именно в здоровой семье?» [7, с. 193, 194].

По мнению философа, необходимость в национальном воспитании присуща каждому народу, «только на этом пути человечеству удастся соблюсти священное начало родины и в то же время одолеть соблазны - как больного национализма, так и все разлагающего интернационализма» [6, c. 208].

Иван Александрович считал национализм любовью к духовному своеобразию народа и его духу, своего рода защитной реакцией народа на искажение основ бытия и национального духа. Национализм в этом свете выступает в качестве чувства любви к своей Родине, в отличие от современной трактовки, понимающей национализм как идеологический и политический термин, который представляется в извращенном понимании как разжигание межэтнической и межнациональной вражды, замкнутая обособленность внутри и недоверие к другим нациям. Философ понятия «национализм» и «патриотизм» ставит близко друг к другу, но у него «национализм» более узкое понятие. «Национализм» - это одна из составных положительных частей патриотизма. Всё, что сегодня приписывается отрицательного онятию «национализм» - обособленность народа, его самомнение, ненависть и враждебное отношение к другим народам, - Ильин трактовал как извращение этого понятия и говорил о том, что необходимо уважать национальные чувства и духовность других народов.

Ильин считал, что если национализм понимается правильно, то национальная культура произрастает из творческого единства национальных и религиозных чувств. Национализм не идёт в противоречие с христианскими ценностями потому, что каждой нации присущ свой особенный «религиозный смысл», а «религиозная вера осмысливает национализм, а национализм возводит себя к Богу» [5, с. 329].

По словам Ильина, только лишь зрелый в духовном смысле человек может быть патриотом и гражданином своей Родины потому, что он бескорыстно, прилагая все силы, будет защищать и стоять насмерть за духовную культуру Отчизны. Именно ради этого и стоит жить.

Истинной, духовной любовью настоящий патриот любит свою Родину, а тот, кто мёртв духовно, её не любит по-настоящему и может предать.

«Сопринадлежность» формирует у людей патриотическое единство, делает единым их духовный уклад. Иван Александрович подчёркивал следующее: «Люди связываются в единую нацию и создают единую родину именно в силу подобия их духовного уклада, а этот духовный уклад вырабатывается постепенно, исторически из эмпирической данности - внутренней, скрытой в самом человеке (раса, кровь, темперамент, душевные способности и неспособности), и внешней (природа, климат, соседи). Вся эта внутренняя и внешняя эмпирическая данность, полученная народом от Бога и от истории, должна быть проработана духом, причём она и со своей стороны формирует дух народа, то облегчая ему его пути, то затрудняя и загромождая их. В результате возникает единый национально-духовный уклад, который и связывает людей в патриотическое единство» 6 , с. 189]. 
Настоящий патриотизм и национализм как его составляющая, как отмечал философ, - это «...любовь не слепая, а зрячая; и парение её не только не чуждо добру и справедливости, и праву, и главное, Духу Божию, но есть одно из высших проявлений духовности на земле» $[6$, с. 217].

Ильин настаивал на том, что надо бороться с национальным обезличи- ванием, приобщая детей с раннего детства к духовно правильному национализму. Воспитание подрастающего поколения - это «пробуждение их бессознательного чувствилища к национальному духовному опыту, укрепление в нём их сердца, их воли, их воображения и их творческих замыслов» $[6$, c. 202].

\section{ЛИТЕРАТУРА}

1. Абишева А.К. О понятии «ценность» // Вопросы философии. 2002. № 3. С. 139-146.

2. Бондарева Я.В. Генезис принципа трансцендентности как методологической основы русской религиозной мысли // Вестник Московского областного государственного университета. Серия: Философские науки. 2009. № 2. С. 14-24.

3. Бондарева Я.В. Единство веры и знания как базовый гносеологический принцип русской религиозной философии середины XIX - первой половины XX веков (статья вторая) // Вестник Московского государственного областного университета. Серия: Философские науки. 2010. № 1. С. 23-27.

4. Гринер Ф.Т. Ильин о патриотизме как всечеловеческой ценности // Культурологический журнал. 2015. № 4 (22). С. 8.

5. Ильин И.А. Основы христианской культуры // Собрание сочинений: в 10 т. Т. 1. М.: Русская книга, 1996.

6. Ильин И.А. Путь духовного обновления // Собрание сочинений: в 10 т. Т. 1. М.: Русская книга, 1996.

7. Ильин И.А. Путь к очевидности. М.: Республика, 1993. 432 с.

8. Каримов Р.Р. Патриотизм как форма общегражданской идентификации россиян: на основе учений И.А. Ильина // Вопросы политологии. 2012. № 4 (8). С. 104-111.

9. Слукин С.В. Патриотизм в социокультурном развитии личности: дис. ... канд. филос. наук. Екатеринбург, 2005. 194 с.

10. Станкевич А.Р. Нравственные принципы и проблема становления личности в философии И.А. Ильина: дис. ... канд. филос. наук. СПб., 2010. 144 с.

\section{REFERENCES}

1. Abisheva A.K. [On the Concept of "Value"]. In: Voprosy filosofii [Russian Studies in Philosophy], 2002, no. 3, pp. 139-146.

2. Bondareva Ya.V. [The Genesis of the Principle of Transcendence as A Methodological Basis of Russian Religious Thought]. In: Vestnik Moskovskogo oblastnogo gosudarstvennogo universiteta. Seriya: Filosofskie nauki [Bulletin of Moscow Region State University. Series: Philosophy], 2009, no. 2, pp. 14-24.

3. Bondareva Ya.V. [The Unity of Faith and Knowledge as the Basic Epistemological Principle of Russian Religious Philosophy of the middle 19th - early $20^{\text {th }}$ Centuries (the Second Article)]. In: Vestnik Moskovskogo oblastnogo gosudarstvennogo universiteta. Seriya: Filosofskie nauki [Bulletin of Moscow Region State University. Series: Philosophy], 2010, no. 1, pp. 23-27.

4. Griner F.T. [Ilyin on Patriotism as a Universal Human Value]. In: Kul'turologicheskii zhurnal [Journal of Cultural Research], 2015, no. 4 (22), pp. 8. 
5. Ilyin I.A. [The Basics of the Christian Culture]. In: Sobranie sochineniy. T. 1. [Collected Works. Vol. 1]. Moscow, Russkaya kniga Publ., 1996.

6. Ilyin I.A. The Path of Spiritual Renewal. In: Sobranie sochineniy. T. 1. [Collected Works. Vol. 1]. Moscow, Russkaya kniga Publ., 1996.

7. Ilyin I.A. Put' $k$ ochevidnosti [The Path to the Obvious]. Moscow, Respublika Publ., 1993. $432 \mathrm{p}$.

8. Karimov R.R. [Patriotism as a Form of Civil Identity of the Russians: on the Basis of the Teachings of Ivan Ilyin]. In: Voprosy politologii [Issues of Political Science], 2012, no. 4 (8), pp. 104-111.

9. Slukin S.V. Patriotizm v sotsiokul'turnom razvitii lichnosti: dis. ... kand. filos. nauk [Patriotism in Sociocultural Development of the Personality: PhD thesis in Philosophy]. Ekaterinburg, 2005. 194 p.

10. Stankevich A.R. Nravstvennyye printsipy i problema stanovleniya lichnosti v filosofii I.A. Il'ina. Dis.... kand. filos. nauk [Moral Principles and the Problem of Personality in I.A. Ilyin's Philosophy]. PhD thesis in Philosophy]. St. Petersburg, 2010. 144 p.

\section{ИНФОРМАЦИЯ ОБ АВТОРЕ}

Потапенко Татьяна Владимировна - аспирант кафедры философии Московского государственного областного университета;

e-mail: vestimo@progtech.ru

\section{INFORMATION ABOUT THE AUTHOR}

Potapenko Tatiana V. - postgraduate student the Department of the Philosophy, Moscow Region State University;

e-mail: vestimo@progtech.ru

\section{ПРАВИЛЬНАЯ ССЫЛКА НА СТАТЬЮ}

Потапенко Т.В. Идея патриотической основы личности в философии И.А. Ильина // Вестник Московского государственного областного университета. Серия: Философские науки. 2017. № 3. С. 81-87

DOI: $10.18384 / 2310-7227-2017-3-81-87$

\section{CORRECT REFERENCE TO ARTICLE}

Potapenko T.V. The Idea of Patriotic Foundations of Personality in I.A. Ilyin's Philosophy. In: Bulletin of Moscow Region State University. Series: Philosophy, 2017, no. 3, pp.81-87

DOI: $10.18384 / 2310-7227-2017-3-81-87$ 